\title{
Lighting Out for the Territory Back East: Ellis Parker Butler, American Humorist
}

\author{
H E N R Y B. C H A P I N
}

\section{From Pork Packing . . .}

Ellis Parker Butler wanted to leave Muscatine. He had lived for 27 years in the small Iowa town overlooking the Mississippi River. For roughly half that time, he had worked in the town's mills and stores since leaving school after the ninth grade. Butler later said about this pivotal period in his life:

In 1896 I was pursuing my literary career, and almost catching up with it, while I sent my manuscripts to New York and sold prunes to Charley Fuller and navy beans to Otto Brothers and sardines and clothespins to Frank Witman. I happened to visit New York with a friend and I asked three editors if they thought I should come to New York. "Are you the fellow who is writing in Iowa and sending your manuscripts to New York?" they asked. "Yes, I am," I said breathlessly. "Then by all means," they said, "do come to New Yorkand send your manuscripts to Iowa."I

Butler soon acted on this lighthearted advice and went east for opportunity. Like so many midwestern writers and others who aspired to the intellectual trades, he really had no option at the time. Moreover, this eastward move came not long after the closing of the frontier, according to the Turner thesis. ${ }^{2}$ Thus, Butler reversed the steady westward movement of the Butler family since Patrick Butler left Tipperary, Ireland, about 1750 and married an American woman in Lebanon, Connecticut. ${ }^{3}$ During the nineteenth century, the But-

1 Elsie Butler Waller, "A Lifetime of Letters to a Daughter," unpublished paper, p. 4. Copy in The University of Iowa Libraries.

2 Frederick Jackson Turner, The Significance of the Frontier in American History, ed. Harold P. Simonson (New York: Frederick Ungar, 1963), p. 27. Turner quotes the 1890 census to the effect that the frontier closed in 1880 .

3 Bryant Ormond Butler, The Butler Family of Lebanon, Connecticut (Rutland, Vermont: The Tuttle Co., 1934), pp. 38-39. 
lers had wended their way along the Ohio River from Cincinnati to the Mississippi River town of Muscatine. The family was in the pork-packing business. Cincinnati was often noted in the last century for the plethora of pigs in its streets, and anyone in the business would have found the westward route along the rivers a natural one to follow.

Muscatine must have been the scene of a Tom Sawyer-like boyhood for Butler. Novels like Swatty and Jibby Jones, along with numerous stories about the town of Riverbank, evoke the idyllic aspect of being a boy in those halcyon, small-town days. Nevertheless, the reality of Butler's life was mainly work once he had left school. Muscatine, despite the many testimonials to its genial beauty, must also have seemed limited. ${ }^{4}$

The young Butler knew what he really wanted to do. After all, he had been writing since he was $11 . .^{5}$ And he had published his first story when he was 13. Its title was "Shorty and Frank's Adventure," and he was paid all of 50 penny postcards for his labor. ${ }^{6}$ The aspiring writer had held and lost several clerk's jobs, and he did his writing at night. He frequently changed jobs, but he must have been developing business acumen which would eventually aid him as vice-president of the First National Bank of Flushing and president of the Authors' League.

Perhaps Butler stayed in Muscatine as long as he did because he felt a great burden to take care of other members of his family. For example, when he married, he vowed he would never wash another dish because he had already washed so many for his family. ${ }^{7} \mathrm{~A}$ similar relaxation from drudgery in his life may be deduced from the fact that, once married, his writing routine often began with breakfast in bed. ${ }^{8}$

His devoted wife made this pleasing regimen possible. Ida Zipser was the daughter of an itinerant German musician from Leipzig who one day kept on traveling while leaving his family behind forever. This, along with his harsh musical discipline, did not endear his memory to his daughter. ${ }^{9}$ Nevertheless, her future husband was

4 William J. Petersen. "Beginnings of Muscatine," Palimpsest 45, no. 9 (Sept. 1964). This entire issue is on Muscatine. For a recent celebration of Muscatine's charms, see Jonathan Raban, Old Glory: An American Voyage (New York: Simon and Schuster, 1981), pp. 192-207.

5 Waller, p. 2.

6 "Portrait," Saint Nicholas 63 (Nov. 1935): 1.

7 Personal conversation with Ida Zipser Butler, late forties or early fifties.

8 Waller, p. 14.

9 Personal conversation with Jean Butler Chapin. 
particularly fond of the many Germans in Muscatine. He later "gratefully inscribed" Swatty to Fred Ernst Schmidt, "faithful companion of my boyhood."10 His pro-German attitude was later to undergo strain during World War I.

He met his wife while ice skating. Ida Zipser was a girl, ten years younger than he, who happened to be last in a line of skaters playing Snap the Whip, a game with the object of hurtling the final skater across the ice. Apparently, the young girl sailed across the ice and bumped into the shy man. ${ }^{11}$

Without the means to marry her yet, the 28-year-old Butler struck out in 1897 for the Big City in the East where opportunity and success lay. He worked at a salary of $\$ 15$ a week as an editor of an interior decorating magazine. ${ }^{12}$ At last he was in a position to commit himself wholeheartedly to his true vocation.

From this time on in New York, Butler regularly published stories, essays, and light verse. His work appeared in such magazines as Century, National Magazine, Lippincott, American Magazine, McClure's, Cosmopolitan, Harper's, Puck, and Judge. When compared to today's magazines, the great number and the bountiful contents of these earlier magazines are amazing. It was commonplace for an issue to have five or six stories. There was no doubt that a market existed for the aspiring writer, and Butler must have sold enough pieces to enable him to return to Muscatine to marry.

The serendipitous moment on the ice culminated in his marriage in 1899. Thereafter, Butler seldom returned to Muscatine except in his imagination, though years later he was to write of one visit when he sought out his birthplace on Third Street. All he could find, however, was the word "ICE" written on the door. He tried to make himself believe it stood for "In Commemoration of Ellis," but regretfully concluded that no author is a hero in his home until he is dead. ${ }^{13}$

Upon arriving in New York City, Butler and his new wife moved to a boardinghouse and then to various apartments in the Morningside Heights-Riverside Drive section of New York City. It was an urban existence, and it suggests that Butler was part of the great

10 Swatty (Boston and New York: Houghton Mifflin, 1920).

11 Personal conversation with Ida Zipser Butler. On Butler's shyness, see "Poor Old Ellis Parker Butler Is 50 This Month," American Magazine 88 (Dec. 1919): 38-39. In this essay, he says he had more worries when young, especially getting up enough courage to ask a girl to marry him.

12 "I Wish I Had Not Been a Well-Frog," American Magazine 89 (Mar. 1920): 66-67.

13 "Back to the Old Home Town." American Magazine 89 (May 1920): 26-27. 
move to the cities which, in addition to the closing of the frontier, became such an important part of America's development at the turn of the century. ${ }^{14}$

After a few years, Butler moved with his wife and new daughter, Elsie, to the suburb of Flushing, Long Island. He later explained that, "it was the most beautiful town we had ever seen." "It looked like a home town," he added. ${ }^{15}$ It was a hometown that would inexorably become citified once it became the last stop on the subway. Nevertheless, Flushing had a definite small-town feeling during the early part of this century. Yet New York was very near. Perhaps the family had the best of both worlds by living in a Muscatine-onthe-Subway. The family resided in Flushing for the next three decades. Muscatine was now permanently in the past except in his stories.

There was a brief interlude in Paris during the winter of 190607 when the proceeds from "Pigs Is Pigs," his best-known work, enabled the family to travel. Ernest Blumenschein, the artist who was later to help found the Taos, New Mexico, artists' colony, urged the Butlers to come to Paris. While there, Blumenschein painted a remarkable family portrait which later won a gold medal in a show in Philadelphia. ${ }^{16}$

But the experience in Paris does not seem to have been as profound as it was to be for the expatriate writers of the twenties. Perhaps Butler had gone too far east this time. Blumenschein suggested in a letter that Paris might not be permanently rewarding:

You must come to see: not as Americans mostly do, to compare. Open your eyes and shut your memory; then start out around Europe to find beauty. . . . It may not be satisfying because we are Americans, and beauty and art are not life now-a-days. Some other big thing is life and that will pull you back to Flushing. ${ }^{17}$

Butler claimed that the only French he learned there was "low show," his version of teau chaud, and only a few slight pieces seem to have come out of the visit. ${ }^{18}$

Undoubtedly, Butler needed the fertility of American cultural soil to nourish his writing. He never expressed the slightest sense of alienation from American culture. Upon returning from Paris, he

14 Telephone interview with Daniel Boylan, July 1982.

15 "Why I Live in a Suburb," American Magazine 103 (Mar. 1927): 214.

16 Waller, p. 10.

17 Waller, p. 9.

18 "Many Happy Returns of the Day," American Magazine 98 (Nov. 1924): 190. 
settled down to raise a growing family in Flushing. The man who later was to be facetiously described as one of the most famous authors in Flushing became a solid citizen of the town, and he took on many duties. 19

In his own terms, he tended to gather "goat-feathers," or distractions from his main business of writing. He was a bank official; president of the Authors' League, an organization dedicated to getting better contractual arrangements for writers; and an active participant in Queens Borough Democratic and Fusion politics. He also became a popular lecturer, even at one time planning a tour with Joyce Kilmer. ${ }^{20}$ All of these activities were facets of a full life, but it is also true that Butler's own perception was that he tended to waste time. We can gain a measure of insight into this side of Butler from his tribute to another Muscatine German, Adolph Pietz. Butler particularly admired the singleminded dedication of Pietz who, despite his poverty, devoted his life to a machine invention of his. ${ }^{21}$ Why did Butler admire this idealism? Because, according to his own testimony, he felt he lacked this quality and was too easily distracted.

Butler's touchingly engaging Goat-Feathers, an essay published as a slim volume in 1919, makes a candid statement about his excessive readiness to volunteer. "Goat-feathers" is his term for "the distractions, side lines, and deflections that take a man's attention from his own business and keep him from getting ahead." $22 \mathrm{He}$ is "firmly convinced that there is now extant an Association to Prevent Butler Doing a Full Day's Work."23 And he ruefully adds:

No man in the world had a better chance to make himself the Great American Humorist than I had when I wrote "Pigs Is Pigs." I had a good solid foundation of fairly good humorous work under it and the little story had a wonderful success. The thing for me to have done then was to stick to humor, regardless of anything." 24

He was being too hard on himself. One estimate of his total production is 33 books and "over 2,000 stories." 25 This estimate probably

19 "Queens Houses Loath to Use New Numbers; Mixed System Complicates Mail Delivery," New York Times, 21 Aug. 1927.

20 Letter to Joyce Kilmer, 20 Mar. 1917, Ellis Parker Butler Papers, The University of Iowa Libraries, Special Collections, Iowa City, Iowa (hereafter called Iowa Papers).

21 "The Idealist," Bookman 61 (Mar. 1925): 13-21.

22 Goat-Feathers (Boston and New York: Houghton Mifflin, 1919), p. 6.

23 Goat-Feathers, p. 14.

24 Goat-Feathers, p. 18.

25 "Portrait," p. 1. 
errs on the side of generosity as it is in excess of what the bibliographical sources reveal. Nevertheless, it suggests the size of his work despite his feeling of having gathered too many "goat-feathers."

$\mathrm{He}$ also became a popular pundit who lightly commented on the passing scene. The New York Times occasionally reported his pronouncements which were often, but not always, made with tongue in cheek. In a serious vein, he became an outspoken patriot during World War I. For example, Dan Beard, the illustrator and Boy Scout leader (who was also another Flushing luminary), supported Butler in the belief that German books ought to be removed from the shelves of public libraries. ${ }^{26}$ It was Butler's only illiberal moment. But even this serious issue was lightened when he wrote a letter to the Times lambasting a gloomy lady who objected to chewing gum being distributed to the doughboys. Butler took the more liberal side of this debate by saying that, "If our boys, over there to rip the hides off the German, want to chew gum, let 'em chew." 27 He continued his patriotic utterances by stating that all the boys in the U.S. Army could hardly wait to go and, he added, "You can trust our boys to go to the clean place." ${ }^{28} \mathrm{He}$ was referring to the movies our boys would choose over the iniquitous foreign saloons. Butler was always capable of irony but little given to cynicism, so it is difficult to judge the extent of his piety on this occasion.

More often, he was quite content to be the humorist, as on the occasion when he led a Quixotic fight to abolish poison ivy, "about the only thing in Flushing that has not been suppressed." 29 He also printed a piece about the difficulty of growing vegetables (although he could have learned how from his wife who was a first-class gardener). ${ }^{30}$ But he was, as usual, just kidding. He also wrote political commentary in the Irish dialect manner of Mr. Dooley. He resurrected Mike Flannery from "Pigs Is Pigs" for that purpose. ${ }^{31}$ Society seemed to need its stand-up philosophers. The humorist was in part a genial sage diverting the public. Butler liked the role, and he played it well.

26 "Dan Beard on Kaiserism," New York Times, 26 Jan. 1918.

27 Letter to New York Times, 22 Sept. 1918.

28 "Here's a Miracle: Y. M. C. A. at War," New York Times, 20 Oct. 1918. As fate would have it. Butler's four-year-old son at this time, Ellis Olmstead, was eventually to acquit himself admirably in the thick of the action against the Germans in World War II.

29 "Down with Poison Ivyl" New York Times, 2 Oct. 1913.

30 "My Selective Garden," New York Times, 19 Mar. 1911.

31 "Mike Flannery Discusses the Political Campaign," New York Times, 26 May 1912. "Mike Flannery on the Unterrified Democracy," New York Times, 23 June 1912. 
The writer's life in Flushing became a routine of writing, speaking, banking, and parenting. Another interlude occurred in the school year of 1919-20 when the family went to southern California where Butler seems to have been astounded that geraniums could grow all year and become enormous. A photograph survives from that time of Butler balancing precariously on the wing of a firmly grounded biplane. With his airman's hat, goggles, pipe, and business suit he smiles in ironic terror at the earth three feet below. He is the picture of the humorist enjoying life. According to Butler's son, the picture was taken while the family was in California for the filming of The Jack-Knife Man with King Vidor. ${ }^{32}$ But the trip to California was only an incident in the Flushing idyll.

Perhaps California was too far west for Butler, for he soon returned with his family to Flushing where they flourished in the twenties. He published prolifically during this decade (over 85 stories and 10 books), but then came the event which hit the Butlers as hard as it hit the nation: the Great Depression. Economically, a writer functions as an entrepreneur who creates the goods he markets. Writing is the last cottage industry. Butler's normally unpredictable income, stabilized by loans using future writings as collateral, was aggravated by the public's lack of money.

Ultimately, Butler and his wife left the 242 State Street house that had been home for so many years, and they moved to Williamsville, a tiny settlement in the Berkshire Hills of Massachusetts. He continued to write, and he published "The Tuckle Beard" in the soon-to-be-famous Story in 1935.33 As late as 1936, in letters to his daughter Jean, he refers to writing stories. ${ }^{34}$ In April and May of 1937, he published mystery stories for girls. ${ }^{35}$ During this period, frequent references to pain ominously intrude into his letters. The pain came from the cancer complicated by diabetes that ended his life at the age of 68 on the sad day of September 13, 1937.

\section{II ... to "Pigs Is Pigs"}

The obituary that appeared in the New York Times the next day was thorough and appreciative. It also discussed "Pigs Is Pigs," the story indissolubly linked with Butler's name. The writer says about the story, "For the rest of his life its popularity plagued him and he often complained that his name never appeared in print without

32 Letter from Ellis Olmstead Butler, 11 May 1981.

33 "The Tuckle Beard," Story 6, n.s. 34 (May 1935): 71.

34 Letter to Jean Butler Chapin, 12 Nov. 1936.

35 "The Hurry-up Mystery," American Girl, April 1937, p. 17. "The Red Avengers' Mystery," American Girl, May 1937, p. 18. 


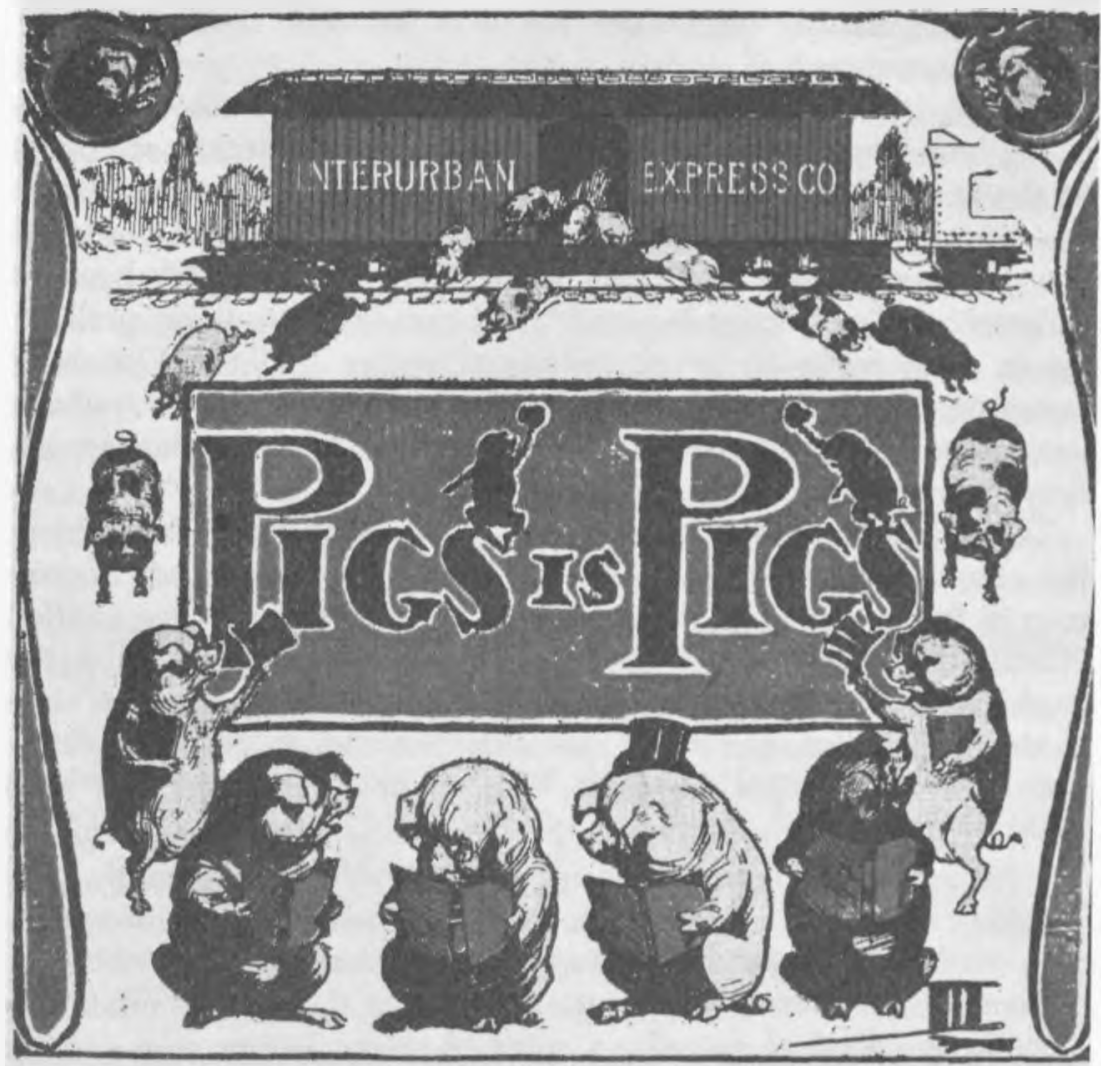

Front cover of the rare first edition of Ellis Parker Butler's famous story Pigs Is Pigs (Chicago: Railway Appliances Company, 1905). From a copy in the lowa Authors Collection. 
the clause, "author of "Pigs Is Pigs." " 36 "Plagued" and "often complained" are harshly inaccurate, but it is true that Butler was invariably introduced as author of the story.

In 1905, American Magazine published the story about the multiplying guinea pigs, and it made Butler an instant literary celebrity. At the heart of "Pigs Is Pigs" is a literal-minded Irish stationmaster who bureaucratically insists, with inflexible logic, that a shipment of two guinea pigs must be treated as a shipment of livestock because "rules is rules" and "pigs is pigs." 37 The guinea pigs quickly proliferate in what seems to be geometric proportion until, to Flannery's increasing desperation, hundreds of the beasts overrun the railway station and fill the warehouse while six helpers carry them out in overflowing bushel baskets.

The story fits within the type of comedy that emphasizes chaos, the elimination of all bounds. ${ }^{38}$ This feeling of chaos is not uncommon in Butler's writing. Twenty-seven years later, in a piece entitled "Civilization Smashes Up," Butler was to say that chaos rules the world and, considering that the year was 1932, he was pretty close to the mark. Characteristically, he adds that, though chaos may rule, optimism will win out eventually. ${ }^{39}$ In addition, Flannery is a rigid blocking character who thinks that manmade rules may stem the inevitable urge of living creatures to be fruitful and multiply. The blocking character is normally a stern father who stands in opposition to the marriage of his daughter to an unacceptable suitor, so Flannery is, of course, only a variation on that theme. ${ }^{40}$ As often happens in this kind of comedy, a spirit of reconciliation reigns at the end, and the blocking character relents so he will be acceptable. In this case, Flannery continues to assert the rules, but he sees them in a more flexible way:

There were only a few guinea-pigs left. As he noted their limited number his natural habit of looking on the bright side returned.

"Well, annyhow," he said cheerfully, "'tis not so bad as ut might be. What if thim dago pigs had been elephants!"41

36 "E. P. Butler Dead; Noted Humorist," New York Times, 14 Sept. 1937.

37 "Pigs Is Pigs" is a short story. However, it has been published at least sixteen times in book form. Since it is a story, the title will be put in quotes except when a book version is unambiguously meant.

${ }^{38} \mathrm{My}$ colleague, David Alethea, first pointed out to me the tendency of comedy to break out of all bounds.

39 "Civilization Smashes Up," Saturday Review of Literature 8 (16 Aug. 1932): 780 .

40 Northrop Frye, Anatomy of Criticism (Princeton, N.J.: Princeton Univ. Press, 1971), pp. 163-186.

41 Pigs Is Pigs (Garden City, New York: Doubleday, Page, 1925), p. 37. 
Optimism defeats chaos!

"Pigs Is Pigs" also fits into Bergson's ideas on comedy in that Flannery's rigidity sets up an absurd premise out of which the humorous logic of the comic plot flows. In Bergson's language, we laugh because of "Something mechanical encrusted on the living. . . ."42 In Butler's story, the mechanical rules of the Westcote Interurban Express Company are no match for the fertile guinea pigs. Certainly "Pigs Is Pigs" joyfully celebrates the fact of birth.

The story is also an example of dialect humor in the tradition of Mark Twain. In this case, the Irish dialect is supposed to be intrinsically humorous. As E. B. White has pointed out, dialect humor sometimes tended to rest on erratic spelling. ${ }^{43}$ In the following example, "agint" and "consign-ey" do not seem to affect the pronunciation of the words, but most of the dialectical spellings appear to be faithful renderings of an accent now seldom heard in America:

Flannery reached for the book. He ran his hand through the pages and stopped at page sixty-four.

"An' I don't take fifty cints," he whispered in mockery. "Here's the rule for ut. 'Whin the agint be in anny doubt regardin' which of two rates applies to a shipment, he shall charge the larger. The consign-ey may file a claim for the overcharge.' In this case, Misther Morehouse, I be in doubt. Pets them animals may be, an' domestic they be, but pigs I'm blame sure they do be, an' me rules say plain as the nose on your face, 'Pigs Franklin to Westcote, thirty cints each.' An', Misther Morehouse, by me arithetical knowledge two times thirty comes to sixty cints." ${ }^{44}$

Altogether, the dialect reveals a verbal exuberance, another common quality of comedy, without the meaningless excesses White points out in Petroleum V. Nasby. Also, because dialect humor was fashionable at one time, White notes the perishable quality of much of it.45 But "Pigs Is Pigs" has had a long life; in fact, it is still in print. The story is an enjoyable view of the foibles of humanity rather than a scathing indictment of blind adherence to regulations. This underlying gentleness probably contributes to the story's effectiveness.

The catchy title must also have helped to make the story memorable. Where did the title originate? Butler initially came up with the

42 Henri Bergson, "Laughter," in The Comic Vision, ed. Peter J. Monahan (New York: McGraw-Hill, 1971), p. 155.

43 E. B. White, "Some Remarks on Humor," in The Comic Vision, pp. 81-83. 44 Pigs Is Pigs, pp. 6-7.

45 White, pp. 80-81. 
indisputably mortal titles "Guinea Pigs in Pawn" and "The Dago Pig Episode." One has the uncomfortable feeling that either title might have killed the story's chances. According to Ellery Sedgewick, editor of American Magazine, someone on the staff of its predecessor, Leslie's Monthly, vetoed the author's title and plucked the fortunate phrase from the story's text.

But where did the phrase come from? Apparently, Butler had clipped from a Liverpool, England, newspaper the following anecdote: an Irish stationmaster in dog-loving England (where dogs may even today ride free on trains if held on the lap) had refused to allow a tortoise to ride free on his train. Evidently fed up with liberal interpretations of the rules, his reasoning was "Dogs is dogs, and cats is dogs, and squirrels in cages is dogs, but that animal is an insect and must pay." Butler wrote his story, rewrote it twice, and changed the phrase "dogs is dogs and cats is dogs" to "pigs is pigs." 46

In a curious coda to this story, Homer Croy notes that the title continued to be problematical. Little did anyone dream that the story would one day become a Walt Disney cartoon. "When the editor got the story back from the printers," Croy says, "he was surprised to find out what a conscientious proofreader had written on the margin. For 'Is' he had put a question mark and the word 'Are?' "47

Another anecdote connected with the story concerns the Iowa State Historical Society's request for a free copy. Butler's inscription long delighted the hapless curator who had unwittingly ignited the candid feelings of a professional writer asked to donate his work. Fred W. Lorch tells the anecdote:

The copy of Pigs Is Pigs that presently came to the curator's desk was inscribed by the author, as he had requested, but hardly in a fashion he had anticipated. On the fly leaf was penned the following verse:

To lowa

Dear Iowa

State of my birth

Accept this book-

A quarter's worth

Oh State of com

Take it from me

And ever let

Thy motto be-

46 "Chronicle and Comment," Bookman 39 (Mar. 1914): 14.

47 Homer Croy, What Grandpa Laughed At (New York: Duell, Sloan and Pearce, 1948), p. 109. 
"Three millions yearly for manure But not one cent For literature."

Ellis Parker Butler

Nothing made [Edgar R.] Harlan prouder in later years than to get out the inscribed copy of Pigs Is Pigs and point to Butler's poem. ${ }^{48}$

Apparently the whole episode had a salutary impact, for Butler advised Harlan to "pressure the legislature for funds for the purchase of books for the Historical Library." According to Lorch, the "bitingly satiric" last stanza helped to ensure that the funds would be allocated. 49

The role of good luck and good humor in the whole history of "Pigs Is Pigs" seems uncanny in retrospect. In a letter, Butler says to a correspondent that he had no idea "Pigs Is Pigs" was anything more than just another story for Ellery Sedgewick. ${ }^{50}$ But it was. Those two guinea pigs produced not only litters and literature but . . .

\section{Letters as Well}

The University of Iowa holds a large collection of Butler's letters and manuscripts containing both confirmation and surprises. One surprise, for example, is an unpublished manuscript of a bawdy poem entitled, with double entendre, "Clap In, Clap Out." The manuscript of a limerick also suggests that, like Mark Twain, Butler had a ribald side:

There was a young lady of Flushing

Her manner was girlish and gushing;

When she stood on her head

In her nightie, she said:

"You can't see my face but I'm blushing."51

An interesting series of letters in the Iowa collection is addressed to Raymond Davis, a benign pest who had apparently latched on to Butler in an irritating yet engaging manner that elicited some meaty responses. The two got off to a poor start with an accusation by Butler of plagiarizing "Pigs Is Pigs," but we can infer Davis's hero worship from the mention of a check that had Butler's signa-

48 Fred W. Lorch, "The 'Pigs Is Pigs' Phenomenon," The Iowan (Winter 1964): 52.

49 Lorch, p. 52.

50 Letter to Courtman House, 7 Jan. 1927, Iowa Papers.

51 TS, Iowa Papers. 
ture torn off it. ${ }^{52}$ Some years later, Butler paternally refers to Davis as "son" and denies him permission to dramatize "Pigs Is Pigs" because it is an "exceedingly valuable property," though he generously qualifies this by saying that an amateur performance would be all right. Butler enforces his denial jauntily, "Blood and bones! Scull [sic] and cross bones! Death! Fair Warning!" And then he appends a note that indicates the frustration of many an author imposed upon by an admirer, “And you didn't even enclose a postage stamp for reply!"53

Months later, the pesky Davis predictably asked Butler to read a manuscript. In a very pithy letter, Butler asserts that writers really want praise, not criticism, a sound generalization if ever there was one. He then goes on to comment upon the paradoxical nature of criticism:

I can criticize your manuscripts without seeing them. I say "While these manuscripts show that they are by an inexperienced writer, there is nothing that a more extended period of writing could not overcome. . . The best criticism for any manuscript is to send it to an editor. ... If you are writing sugar and my basic impulse is quinine, I'll inevitably say "What you need is more quinine in your sugar." If you take that advice you'll ruin your sugar.

Butler then clinches his argument with the unanswerable conundrum, "If you don't take the advice, why ask it?"

In another letter, Butler takes Davis to task for condemning his story "Fendenton Roper." Butler says it is a good story and discusses how it is based on a real person disguised beyond recognition, thus illuminating the way he created characters.

As a child in Muscatine, Butler had lived much of the time with a cultured aunt, and he had developed educated tastes despite his scanty schooling. As an example, he tells Davis in the same letter that his first loves in literature are Dickens, Twain, Thackeray, and Balzac. He praises Twain because his characters were individuals and then says, "If you read most of the American humorists, you'll see that they did not have that art; they were funny but they were not portrait sketchers." 55

In yet another letter to the persistent Davis, Butler wonders, "There's no telling why I answer your letters. Probably because they read as if you had more or less cayenne in your bean. . ."56 Two

52 Letter to Raymond Davis, 19 Dec. 1918, Iowa Papers.

53 To Davis, 22 Apr. 1924, lowa Papers.

54 To Davis, 19 Dec. 1924, Iowa Papers.

55 To Davis, 9 June 1925, Iowa Papers.

56 To Davis, 29 June 1925, Iowa Papers. 
years later the note of exasperation had disappeared, and Butler is passing on the personal good news that his twin daughters were graduating from high school and his daughter Elsie, who had taken a secretarial course after her graduation from Smith College, had just landed a job at the New Republic. 57

The Iowa collection is eclectic and gives a variety of disparate glimpses into the life of an author. Other items, which might be briefly mentioned to give the flavor of the collection, are a letter from Hamlin Garland saying he had a small income, a letter indicating the motion picture rights to "Pigs Is Pigs" had been sold to Edison, some rejection slips (indicating no author is immune from this curse), a letter from Ellery Sedgewick enclosing an article on "bunnies" multiplying, nine letters from Witter Bynner, including one suggesting "Pets Is Pets" as the title for a piece, and a letter from Homer Croy asking Butler for his epitaph. There is no record of an answer to that last request.

One letter explains in some detail the goals of the Authors' League, an organization that Butler vigorously supported. Basically, the goals were the improving of business relations between authors and publishers and the assisting of authors in getting the full fruits of their labors. In other letters, Butler talked about letting ideas simmer and grow juicy, and he talks about how a person's best work is done after the age of 50 because years give background and a better understanding of life. ${ }^{58}$

\section{A Better Understanding}

Research into Butler's life and work discloses ample evidence that he was a genuine popular presence in America during the first 37 years of this century. Jeffrey J. Falks has discussed this situation:

So popular was Butler in his lifetime, and so greatly have his books fallen out of favor today, we should expect to find in his work some indication of a shift in popular reading tastes between 1920 and 1935 . In fact, such a shift seems to have taken place in regard to Butler's favorite subject matter, the small town and rural America.59

Falks's view is conjectural though likely. However, he places the dates too early since Butler was still in his heyday during the dates Falks mentions. But certainly the increasing grimness of life during

57 To Davis, 4 May 1927, Iowa Papers.

58 Iowa Papers.

59 Jeffrey J. Falks, "Folk Humor in the Stories of Ellis Parker Butler," Tennessee Folklore Society Bulletin 45, no. 11 (June 1979): 79. 
the depression and increasing urbanization may have made the public swerve from small-town humor.

There is a complementary explanation: humor tends to be locked into its own time. Humor is much more ephemeral than is often realized. ${ }^{60}$ T. L. Masson, one of the three editors who urged Butler to come to New York, concentrates on this quicksilver quality of humor when he refers to "A long line of so-termed native humorists -all of whom have been completely forgotten except the poor devils immediately alive. ..."61

During his time, Butler was included with the heady company of Mark Twain, Josh Billings, Artemus Ward, Bill Nye, Finley Peter Dunne, Stephen Leacock, Irvin S. Cobb, George Ade, and Will Rogers. ${ }^{62}$ It was a sterling group to belong to but, except for Twain, they have given way to the Art Buchwalds and Russell Bakers of our day who will give way in turn to yet unknown humorists. In the nature of the case, humorists primarily meet the needs of their own times, and they belong very much to the study of American popular culture.

Butler's writing also contains a solid core that needs to be studied more. For example, "The Blind Ass of the 'Dobe Mill," deals with a blind donkey leading an interminable treadmill existence while it feels it is really traveling to different places. ${ }^{63}$ The story is not humorous; it concludes with a double murder. Yet it is also a parable of reality and illusior, tempered by Butler's characteristic optimism.

A more serious side of Butler also emerges in his many essays like Goat-Feathers or the pieces collected in Hunting the Wow. ${ }^{64}$ Indeed, a volume of the best of Butler would contain as many essays as stories, but the essays are somewhat humorous too.

Novels such as Swatty, The Jack-Knife Man (which Butler was particularly proud of), Kilo, Jibby Jones, and Dominie Dean, all of which hark back to Muscatine days, might profitably be studied. Perhaps the new disciplines of American studies and popular culture would provide the best vantage points for another look at Butler.

Butler was primarily a humorist, and the humorist's work is linked precariously to eternity by its own moment-and for Ellis Parker

60 White, pp. 77-83.

61 T. L. Masson, "Has America a Sense of Humor?" North American Review 228 (Aug. 1929): 178.

62 "American Humorists," National Education Association Journal 14 (Mar. 1925): 101.

63 Century 82 (Aug. 1911): 607-10.

64 Hunting the Wow (New York: The Laugh Club, 1934). 
Butler that time was from 1896 to 1937 . In retrospect, it seems clear that Butler's literary life took place on the other side of a great divide. In a world shaped by World War II and its consequences, Butler belongs to a decisively earlier time. There was more than a little of the Horatio Alger in his life. He came from modest circumstances, had little schooling, yet he went East to find success through optimism, pluck, and luck. It is a quintessentially American story of the period between the closing of the frontier and the ravages of the depression when a man could light out for the territory back East to fulfill his dream! 